\title{
MURABAHAH CONTRACT WITH DELAYING OF HANDOVER OBJECT FOR FINANCING OF MULIA'S PROGRAM (Case Studies at Pegadaian Syariah of Bengkulu)
}

\author{
Esti Alfiah \\ IAIN Bengkulu \\ E-mail: esti.alfiah2107@gmail.com
}

\begin{abstract}
This research find about financing of MULIA's program programs the one of financing method with murabahah contract at Pegadaian. There goods things as a object are holded by Pegadaan. Exactly the purpose of this research is to know how ascept delays object with murabahah contract in prespective of Islamic economic. The kind of this research is descriptive qualitative, and the location at research is Pegadaian Stariah of Bengkulu. And to collect all of data are conducted by interview and documentation. Based on this research can the conclude that implementation at murabahah contract with delaying in handover of object for financing of MULIA's program at Pegadaian Syariah Bengkulu are not suitable with prespective of Islamic economic.
\end{abstract}

Keywords : financing, Murabahah, Rahn, dan MULIA's

\section{PENDAHULUAN}

Produk yang dikeluarkan pegadaian Syariah tidak kalah saing dengan pegadaian konvensional. Salah satu produk yang dikeluarkan baru-baru ini menjadi minat masyarakat yaitu pembiayaan program MULIA yang merupakan kepanjangan dari Murabahah Logam Mulia untuk Investasi Abadi. Pembiayaan program MULIA adalah penjualan logam mulia oleh Pegadaian kepada masyarakat secara tunai atau angsuran dan agunan jangka waktu fleksibel.

Hasil survei yang penulis lakukan pada tanggal 17 juni 2014 di pegadaian syariah menunjukkan bahwa pegadaian syariah maupun konvensional, secara hitungan sama. Secara umum, harga emas batangan yang dijual oleh PT pegadaian akan mengacu pada harga emas batangan yang dikeluarkan oleh PT. Antam ${ }^{1}$. Tambahannya, Pegadaian akan menambahkan margin sekitar 3-36\% dari harga yang dikeluarkan Antam, ditambah lagi biaya administrasi sekitar 50.000

Untuk pembelian tunai tetap dikenakan margin sebesar 3\% dan emas baru 1 ANTAM merupakan perusahaan
pertambangan yang terdiversifikasi dan terintegrasi
secara vertikal yang berorientasi ekspor.
(http://www.antam.com/index.php?option=com_conte
nt\&task=view\&id=32\&Itemid=2), (Akses Tanggal 22
September 2014). 
bisa diterima maksimal 1 bulan dari tanggal beli. Jadi jika emas dibeli hari ini maka selain dikenakan margin 3\%, emas batangannya baru akan diterima 1 bulan mendatang. Untuk pembelian cicil/angsur melalui program MULIA di Pegadaian, maka disyaratkan pembayaran Down payment (selanjutnya akan di singkat DP) sejumlah $25 \%$ dari total harga emas batangan.

Menurut keterangan yang didapat dari petugas pegadaian, dalam pembelian emas logam mulia akad yang digunakan adalah akad murabahah. Setelah pembeli dan penjual bertransaksi kemudian penjual memesan barang sesuai dengan kesepakatan. Pembeli memberikan DP, sisa dari pembelian ditangguhkan oleh pihak pegadaian/ penjual. Barang yang dibeli kemudian ditahan di Pegadaian. Setelah selesai pembelian atau pelunasan baru kemudian barang yang dibeli diberikan kepada pembeli. ${ }^{2}$ Permasalahan yang digarisbawahi adalah kedudukan objek pada pembiayaan program Mulia, murabahah seharusnya pada saat penyerahan barang di awal bukan di akhir.

Menurut jumhur ulama, rukun dan syarat yang terdapat dalam Ba'I murabahah sama dengan rukun dan syarat yang terdapat dalam jual beli, dan hal itu identik dengan rukun dan syarat yang harus ada dalam akad. Menurut Hanafiyah, rukun yang terdapat

\footnotetext{
${ }^{2}$ Wawancara Zulkifli, Pegawai Pegadaian Syariah cabang Bengkulu, Tanggal 17 juni 2014, pukul 10:00 wib 114
}

dalam jual beli hanya satu, yaitu sighat (ijab dan qabul), adapun rukun-rukun lainnya merupakan derivasi dari sighat. Artinya Sighat tidak akan ada jika tidak terdapat dua pihak yang bertransaksi, misalnya penjual dan pembeli, dalam melakukan akad (sighat) tentunya ada sesuatu yang harus ditransaksikan, yakni objek transaksi. ${ }^{3}$

Sebuah hadis yang diriwayatkan oleh Imam Muslim berartikan Dari Abu Hurairah, ra., ia berkata: "Rasulullah saw, melarang menjual dengan cara melempar batu (dari kejauhan) dan melarang dengan gharar (belum diketahui wujudnya). ${ }^{4}$ dan Dari Amr putera Syu'aib dari ayahnya, dari kakeknya, ra., iya berkata : bersabda Rasulullah saw. "tidak dihalalkan pinjaman dan penjualan dan tidak halal dua syarat dalam satu penjualan, tidak halal keuntungan dari hasil penjualan barang yang tidak ada tanggungannya. Dan tidak halal menjual barang yang tidak ada padamu (abstrak)..$^{5}$

Dapat disimpulkan bahwa objek akad Murabahah harus memenuhi barang halal dapat diambil manfaatnya atau memiliki nilai, dimiliki oleh penjual, diserahkan tanpa tergantung dengan kejadian tertentu dimasa depan, spesifik dan dapat

${ }^{3}$ Dimyauddin Djuwaini, Pengantar Fiqh Muamalah (Yogyakarta, pustaka Pelajar, 2010) Hal. 111

${ }^{4}$ Alhafizh Ibn Hajar A'Asqalani, Bulughul Maram. Terj. Moh. Machfuddin Aladin, (Semarang : PT. Karya Toha Putra) Hal. 390

${ }^{5}$ ibid, hal. 392 
diidentifikasi oleh pembeli sehingga tidak ada gharar (ketidak pastian), kuantitasnya dengan jelas, kualitasnya dengan jelas sehingga tidak ada gharar, Harga jelas dan Barang yang diakadkan secara fisik ada di tangan penjual.

Berbeda halnya Praktek Murabahah di Pegadaian Syariah, objek transaksi diserahkan pada pelunasan-jatuh tempo pada pembelian kredit. Sementara pada pembelian cash, penyerahan pun sebulan setelah transaksi. Untuk mengetahui yang sebenarnya bagaimana praktik penundaan objek akad murabahah maka perlu diadakan penelitian pada Cabang Pegadaian Syariah Kecamatan Ratu Agung Bengkulu.

Dapat dirumuskan permasalahan adalah bagaimana penundaan penyerahan objek akad murabahah pada pelaksanaan pembiayaan program MULIA dalam persfektif ekonomi Islam. Tujuan dalam penelitian ini adalah untuk mengetahui penundaan penyerahan objek akad murabahah pada pelaksanaan pembiayaan program MULIA dalam perfektif ekonomi Islam di pegadaian syariah cabang Bengkulu. Adapun kegunaannya secara teoritis yaitu hasil penelitian ini diharapkan dapat menjadi masukan yang positif bagi pengembangan ilmu hukum khususnya Hukum Gadai Syariah dan memperoleh pengetahuan yang lebih mendalam mengenai kedudukan objek Akad Murabahah pada Pembiayaan Program MULIA sedangkan Secara praktis yaitu memberikan jawaban atas permasalahan yang diteliti dan sebagai sosialisasi pegadaian syariah dan khususnya pembiayaan program MULIA.

Penelitian ini adalah deskriptif kualitatif, dilaksanakan pada pegadaian syariah cabang dengan sumber data primer adalah pimpinan cabang pegadaian syariah cabang Bengkulu, penaksir cabang, petugas administrasi pelayanan, dan wawancara nasabah serta arsip pegadaian syariah cabang Bengkulu, sedangkan sumber data sekunder adalah buku-buku lainnya yang berkaitan dengan masalah yang diteliti. Selain itu, teknik Pengumpulan data dengan melakukan observasi awal telah dilakukan pada tanggal 17 juni 2014, wawancara dengan pimpinan pegadaian syariah cabang bengkulu Dony Bachtiar S.E, penaksir cabang Zulkifli S.H, dan petugas Administrasi Pelayanan Hermika Lindayani S.Pd dan kepustakaan. Penelitian ini dengan teknik analisis data yaitu Reduksi data, Penyajian data dan Penarikan kesimpulan.

\section{LANDASAN TEORI}

\section{Akad}

Menurut segi etimologi, akad antara lain berarti ikatan antara dua perkara, baik ikatan secara nyata maupun ikatan secara maknawi, dari satu segi maupun dari dua segi bisa juga berarti sambungan, dan janji. Menurut terminologi akad adalah perikatan yang ditetapkan dengan ijab-qabul berdasarkan ketentuan syara' yang berdampak pada 
objeknya atau Pengaitan ucapan salah seorang yang akad dengan yang lainnya secara syara' pada segi yang tampak dan berdampak pada objeknya. ${ }^{6}$ Akad akan terbentuk apabila memenuhi rukun akad. Menurut Ulama Hanafiyah berpendapat bahwa rukun akad adalah ijab dan qabul. Adapun orang yang mengadakan akad atau hal-hal lainnya yang menunjang terjadinya akad tidak dikategorikan rukun sebab keberadaannya sudah pasti. Sedangkan ulama selain Hanafiyah berpendapat bahwa akad memiliki tiga rukun, yaitu : Orang yang akad ('aqid), contoh : penjual dan pembeli, Sesuatu yang diakadkan (maqud alaih), contoh : harga atau yang dihargakan. Dan Shighat, yaitu ijab dan qabul. ${ }^{7}$

Dapat disimpulkan bahwa dalam akad memiliki beberapa rukun yang wajib ada yaitu ijab dan qabul, di dalam ijab dan qabul ini tentunya terdapat orang yang berakad yaitu penjual dan pembeli, dan sesuatu yang di akadkan yaitu barang atau harga.

\section{Objek Akad}

Mahal Aqd (Al-Ma'qud Alaih) adalah objek akad atau benda-benda yang dijadikan akad yang bentuknya tampak dan membekas. Barang tersebut berbentuk harta benda,

\footnotetext{
${ }^{1}$ Rachmat Syafe'I, Fiqih Muamalah (Pustaka Setia, Bandung, 2004) Hal.43-45

${ }^{7}$ Definisi ijab menurut ulama Hanafiyah adalah penetapan perbuatan tertentu yang menunjukkan keridaab yang diucapkan oleh orang pertama, baik yang menyerahkan maupun yang menerima, sedangkan Qabul adalah orang yang berkata setelah orang yang mengucapkan ijab, yang menunjukkan keridaan atas ucapan orang pertama. 116
}

seperti barang dagangan, benda buka harta, seperti dalam akad pernikahan dan dapat pula berbentuk kemanfaatan, seperti dalam masalah upah-mengupah, dan lain-lain. Dalam Islam, tidak semua barang dapat dijadikan objek akad, misalnya minuman keras. Oleh karena itu, fuqaha menetapkan empat syarat dalam objek akad berikut ini :
a. Ma'qud Alaih (barang) harus ada ketika akad.
b. Ma'ud 'alaih harus masyru' (sesuai ketentuan syara')
c. Dapat diberikan waktu akad.
d. Ma'qud 'alaih harus diketahui oleh kedua pihak yang akad
e. Ma'qud 'alaih harus suci

Berdasarkan unsur akad tersebut, ada beberapa macam syarat akad, yaitu syarat terjadinya akad, syarat sah, syarat memberikan dan syarat keharusan. Syarat terjadinya akad adalah segala sesuatu yang disyaratkan untuk terjadinya akad secara syara'. Jika tidak memenuhi syara' tersebut, akad menjadi batal. Syarat sah Akad adalah segala sesuatu yang disyaratkan syara' untuk menjamin dampak keabsahan akad. Jika tidak terpenuhi akad tersebut rusak dan Syarat Pelaksanaan Akad terdiri dua syarat, yaitu kepemilikan dan kekuasaan. Kepemilikan adalah sesuatu yang dimiliki oleh seseorang sehingga ia bebas beraktivitas dengan apa-apa yang dimilikinya sesuai dengan aturan syara'. Adapun kekuasaan 
adalah kemampuan seseorang dalam diperoleh). ${ }^{11}$ Sedangkan dalam fatwa Dewan bertasharuf sesuai dengan ketetapan syara', Syariah Nasional ( tahun 2006 ) yang baik secara asli, yakni dilakukan oleh dimaksud dengan murabahah adalah menjual dirinya, maupun sebagai penggantian suatu barang dengan menegaskan harga (menjadi wakil seseorang). ${ }^{8} \quad$ belinya kepada pembeli dan pembeli

\section{Murabahah}

Secara logistik, murabahah berasal dari kata ribh yang bermakna tumbuh dan berkembang dalam peniagaan. Secara istilah, terdapat definisi yang diberikan ulama. Di antaranya, Ibnu Rusyd al Maliki mengatakan Murabahah adalah jual beli komoditas di mana penjual memberikan informasi kepada pembeli tentang harga pokok pembelian barang dan tingkat keuntungan yang diinginkan. ${ }^{9}$ Murabahah adalah jual beli barang pada harga asal dengan tambahan keuntungan yang disepakati antara pihak bank dan nasabah. Teknis dalam bai' al Murabahah bahwa dalam transaksi ini, bila sudah ada barang diserahkan segera kepada nasabah, sedangkan pembayaran dilakukan secara kredit. ${ }^{10}$

Akad ini merupakan salah satu bentuk natural certainty contracts, karena dalam murabahah ditentukan beberapa required rate of profit-nya (keuntungan yang ingin

\footnotetext{
${ }^{8}$ Ibid, Hal. 64-65

9 Dimyauddin Djuwaini, Pengantar Fiqh Muamalah, (Yogyakarta : Pustaka Pelajar, 2010) Hal 103-104

10 Heri Sudarsono, Bank Lembaga Keuangan Syarih (Yogyakarta : Ekonisia, 2004) Hal. 62-63
} membayarnya dengan harga yang lebih sebagai laba. ${ }^{12}$ Jadi singkatnya, murabahah adalah akad jual beli barang dengan menyatakan harga perolehan dan keuntungan (marjin) yang disepakati oleh penjual dan pembeli.

Dibawah ini adalah skema murabahah sebagai berikut :

${ }^{11}$ Adiwarman A. karim, BANK ISLAM Analisis Fiqih dan Keuangan, (Jakarta : PT. RajaGrafindo Persada, 2011) Hal. 113

12 Sofyan Syafri harahap, dkk, Akuntansi Perbankan Syariah, (Jakarta Barat : LPEE Usakti, 2010) Hal. 163 



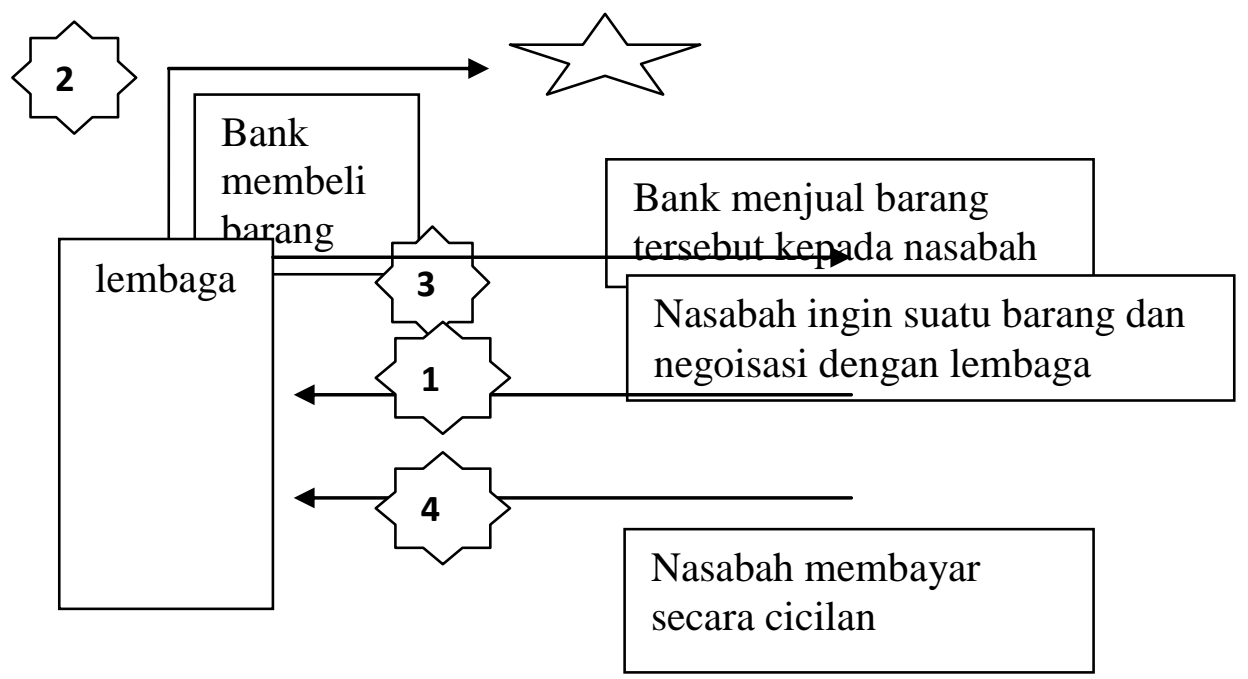

\section{Gambar I Murabahah}

Mengenai Jaminan dalam Murabahah menurut fatwa DSN No: 04/DSN-MUI/IV/2000 Tentang murabahah bahwa Jaminan dalam murabahah dibolehkan, agar nasabah serius dengan pesanannya dan Bank dapat meminta nasabah untuk menyediakan jaminan yang dapat dipegang. ${ }^{13}$ Dapat dilihat bahwa pihak Bank tidak berhak memaksa nasabah untuk memberikan jaminan tertentu kepada bank. Rukun murabahah adalah Penjual (bai'), pembeli (musytariy), barang (mabi'), dan sighat dalam bentuk ijab-qabul. ${ }^{14}$

Adapun Hadis mengenai murabahah yaitu :

\section{عَنْ صُُهَيْبِ رَضِيَّ اللهُ عَنْهُ أَنَّ النَّبَّيَّ

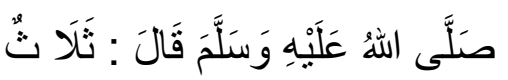

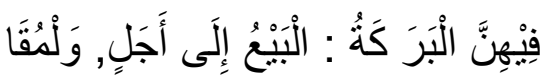

13 Fatwa DSN No: 04/DSN-MUI/IV/2000 Tentang Murabahah Hal. 4

${ }^{14}$ Gemala Dewi, Aspek-Aspek . . ., Hal. 88

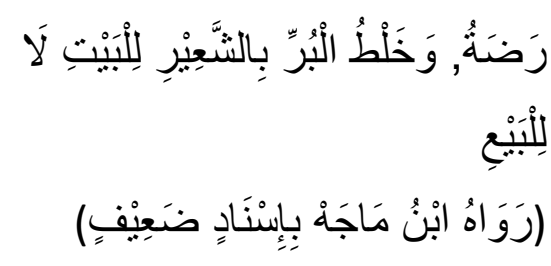

Dari Suhaib Radhiallahuanhu bahwa Nabi Saw bersabda: ada tiga hal yang mengandung berkah, jual beli tidak secara tunai, mudhrabah, dan campur gandum dengan jewawut untuk keperluan rumah tangga, bukan untuk dijual. (HR. Ibnu Majah). ${ }^{15}$

Hadis riwayat Ibnu Majah ini merupakan dalil lain dibolehkannya murabahah yang dilakukan secara tempo. Namun demikian banyak ulama yang menggunakannya sebagai dalil untuk akad mudharabah atau jual beli tempo. Ulama menyatakan bahwa keberkahan dalam arti tumbuh dan menjadi lebih baik, terlebih pada jual beli yang dilakukan secara tempo ataupun akad mudharabah sebagaimana disabdakan Rasulullah SAW dalam hadis tersebut. Dengan menunjuk adanya keberkahan ini,

\footnotetext{
${ }^{15}$ Dimyauddin Djuwaini, Pengantar. .., Hal. 107
} 
hal ini mengindikasikan diperbolehkannya praktik jual beli yang dilakukan secara tempo, begitu juga dengan pembiayaan murabahah yang dilakukan secara tempo, dalam arti, nasabah diberi tenggang waktu untuk melakukan pelunasan atas harga komoditas sesuai kesepakatan.

\section{Gadai (Ar-Rahn)}

Dalam Islam, gadai berasal dari kata Arab al-Rahn yang berarti tetap. Disebut tetap karena barang gadai ada peda pemberi pinjaman hingga utang dibayar. ${ }^{16}$ Gadai juga berarti jaminan utang, gadaian, bnarang yang digadaikan, hipotek, atau al-habs (penahanan), yaitu menahan salah satu harta milik peminjam sebagai jaminan atas pinjaman yang diterimanya. ${ }^{17}$ Dapat dikatakan bahwa rahn adalah bentuk perjanjian yang dilakukan secara tidak tunai atau dalam bentuk utang piutang dengan menggunakan benda sebagai jaminan atas utang itu dan jika dalam waktu jatuh tempo yang telah ditentukan utang tersebut belum terbayar, maka jaminan dapat dijual untuk melunasi utang. ${ }^{18}$

Landasan rahn dalam Al-Qur'an yaitu

Jika kamu dalam perjalanan (dan bermu'amalah tidak secara tunai) sedang kamu tidak memperoleh seorang penulis, Maka hendaklah ada barang tanggungan

16 Idri, Hadis Ekonomi, (Jakarta : Kencana, 2015), hal.197

17 Muhammad syafi'I Antonio, Bank Syariah dari Teori ke Praktek, (Depok : Gema Insani, 2001), Hal. 128 yang dipegang (oleh yang berpiutang). akan tetapi jika sebagian kamu mempercayai sebagian yang lain, Maka hendaklah yang dipercayai itu menunaikan amanatnya (hutangnya) dan hendaklah ia bertakwa kepada Allah Tuhannya; dan janganlah kamu (para saksi) Menyembunyikan persaksian. dan Barangsiapa yang menyembunyikannya, Maka Sesungguhnya ia adalah orang yang berdosa hatinya; dan Allah Maha mengetahui apa yang kamu kerjakan.

Ayat tersebut secara eksplisit menyebutkan Barang tanggungan (borong) itu diadakan bila satu sama lain tidak percaya mempercayai. ${ }^{19}$

Sedangkan dalam Al-Hadis yaitu :

$$
\begin{aligned}
& \text { وَعَنْ أَبِي هُرَيْرَةَ رضي الله عنه قَالَ: قَالَ رَسُولُ }
\end{aligned}
$$

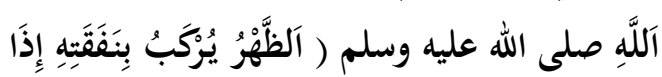

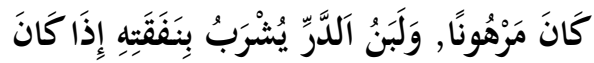

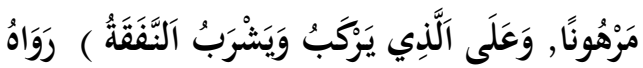

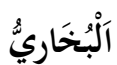

Dari Abu Hurairah Radliyallaahu 'anhu bahwa Rasulullah Shallallaahu 'alaihi wa Sallam bersabda: "Punggung hewan yang digadaikan boleh dinaiki dengan membayar dan susu hewan yang digadaikan boleh diminum dengan membayar. Bagi orang yang menaiki dan meminumnya wajib membayar. ( Riwayat Bukhari). ${ }^{20}$

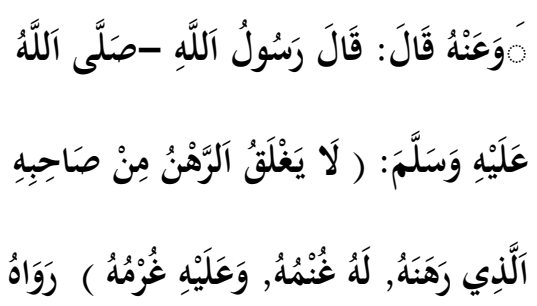

19 Muhammad syafi'I Antonio, Bank Syariah dari Teori ke Praktek...Hal. 128

${ }^{20}$ Moh. Rifa'I dan Qusyairi Misbah, Bulughul Maram.,terjemah. (semarang: CV. Wicaksana, 2004), Hal. 495 


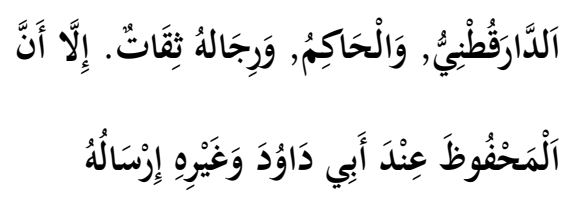

Dari Abu Hurairah Radliyallaahu 'anhu bahwa Rasulullah Shallallaahu 'alaihi wa Sallam bersabda: "Barang gadaian tidak menutup pemilik yang menggadaikannya, keuntungan untuknya dan kerugiannya menjadi tanggungannya.

Riwayat Daruquthni dan Hakim dengan perawi-perawi yang dapat dipercaya. Namun yang terpelihara bagi Abu Dawud dan lainnya hadits itu mursal. ${ }^{21}$

\section{Penelitian Terdahulu}

Untuk mendukung pembahasan yang lebih mendalam mengenai pembahasan di atas, maka penulis berusaha melakukan kajian pustaka ataupun karya-karya yang mempunyai hubungan dengan permasalahan yang akan dikaji. Adapun penelitian yang terkait terhadap hal ini adalah :

Penelitian yang dilakukan oleh Nur Desmi Hasanah dengan judul "Pelaksanaan Rahn (Gadai) Emas pada Bank Pembiayaan Rakyat Syariah (BPRS) Safir Bengkulu dalam Perspektif Ekonomi Islam" menyimpulkan pelaksanaan Gadai Emas Syariah di BPRS Safir Bengkulu menerapkan akad Rahn dan akad Ijarah. Akad rahn yaitu nasabah (rahin) menyepakati untuk menyimpan barangnya (marhun) kepada murtahin di BPRS Safir Bengkulu, sehingga nasabah (rahin) akan membayar sejumlah ongkos kepada murtahin

\footnotetext{
${ }^{21}$ Ibid, Hal. 495
}

atas biaya perawatan dan pemeliharaan terhadap marhun. Akad ijarah merupakan penggunaan manfaat atau jasa pengganti kompensasi (balas jasa). Kedua akad ini tertera dalam Surat Bukti Rahn (SBR).

Berbeda dengan penelitian yang dilakukan oleh Khori Nur Azizah yang dilakukan pada tahun 2012 dengan judul "Pandangan Masyarakat terhadap Pelaksanaan Gadai di Pegadaian Syariah Cabang Bengkulu". Menyimpulkan bahwa pelaksanaan sewa tempat yang ditetapkan oleh pegadaian syariah, sama sekali tidak membuat nasabah merasa keberatan karena sewa tempat/ijarah tersebut seimbang dengan apa yang diberikan pihak lembaga kepada nasabah. Selain itu masyarakat merasa terbantu dengan adanya pegadaian tersebut, walaupun masih banyak nasabah yang belum memahami tentang pelaksanaan gadai syariah.

Sedangkan penelitian yang dilakukan oleh Muklas pada tahun 2010 adalah dengan judul "Implementasi Gadai Syariah dengan Akad Murabahah dan Rahn (Studi di Pegadaian Syariah Cabang Mlati Sleman Yogyakarta). penelitian ini dapat disimpulkan bahwa pelaksanaan Pembiayaan MULIA di Pegadaian Syari'ah Cabang Mlati Sleman Yogyakarta dengan akad murabahah dan rahn telah sesuai dengan hukum Islam dan pegadaian syari'ah telah menerapkan kaidahkaidah hukum Islam seperti terlihat dalam persyaratan yang sederhana, prosedur mudah, akad secara tertulis, pembiayaan/hutang 
dengan jaminan barang yang sudah dibeli, tidak dipungut bunga, keuntungan/margin jelas, perjanjian ditentukan oleh kedua belah pihak dan pembiayaan tidak mengandung gharar.

Lebih lanjut lagi penelitian yang dilakukan oleh Nurul Hikmawati pada tahun 2013 dengan judul "Analisis Fatwa DSN tentang Jual Beli Emas Secara Tidak Tunai (Murabahah Emas), menyimpulkan bahwa Praktik Muamalat jual beli emas dan perak yang dilakukan secara non-tunai di masa Rasulullah SAW, tidak diperbolehkan. Namun di masa sekarang yang terus berkembang, maka para ulama menganalisis kembali agar jual beli emas secara tidak tunai dapat diperbolehkan dengan syarat dan ketentuan yang berlaku.

\section{METODOLOGI PENELITIAN}

\section{Jenis Penelitian}

Jenis penelitian pada skripsi ini adalah deskriptif kualitatif. Deskriptif kualitatif adalah Metode penelitian yang berusaha menggambarkan dan intrepentasikan objek apa adanya. ${ }^{22}$

\section{Tempat Penelitian}

Penelitian ini dilaksanakan pada pegadaian syariah cabang Bengkulu sebagai cabang pegadaian syari'ah dari PT.Pegadaian.

\section{Sumber Data}

22 Mamang Sangadji etta, Sopiah, Metodelogi Penelitian, (Yogyakrta : Andi Yogyakarta, 2010) Hal. 24
Penelitian ini membutuhkan dua jenis data yaitu data primer terdiri dari pimpinan cabang pegadaian syariah cabang Bengkulu, penaksir cabang, petugas administrasi pelayanan, dan wawancara nasabah serta arsip pegadaian syariah cabang Bengkulu dan data sekunder meliputi : Dokumen, yaitu buku-buku lainnya yang berkaitan dengan masalah yang diteliti.

\section{Teknik Pengumpulan Data}

Data-data yang diperlukan dalam penelitian ini, dikumpulkan melalui dua cara yaitu (1) Observasi awal telah dilakukan di pegadaian syariah cabang Bengkulu pada tanggal 17 juni 2014. Informasi didapat dari pegawai pegadaian yang bernama Zulkifli S.H. dan wawancara kepada seorang nasabah. (2) Wawancara mendalam (in depth interview) dengan pimpinan pegadaian syariah cabang bengkulu Dony Bachtiar S.E, penaksir cabang Zulkifli S.H, dan petugas Administrasi Pelayanan Hermika Lindayani S.Pd. dan (3) Kepustakaan ini digunakan dalam rangka memperoleh data sekunder, yaitu dengan cara membaca, mengkaji dan mempelajari berbagai dokumen serta bahanbahan yang berkaitan dengan permasalahan yang diteliti.

\section{Teknik Analisis Data}

Sesuai dengan pendekatan yang digunakan, maka analisis data dilakukan dengan teknik sebagai berikut (1) Reduksi data ( data reduction). Reduksi data adalah proses berupa membuat singkatan, coding, 
memusatkan tema, dan membuat batas-batas permasalahan. Penyajian data ( data display). (2) Penyajian data ( data display). Dengan melihat Penyajian data ( data display), peneliti akan mengerti apa yang terjadi dalam bentuk yang utuh. (3) Penarikan kesimpulan ( conclusi data)

\section{HASIL DAN PEMBAHASAN}

\section{Operasional Pembiayaan Murabahah}

Pegadaian Syariah menawarkan produk Program MULIA (Murabahah Logam Mulia Untuk Investasi Abadi) yang mana Pegadaian Syariah menjual emas batangan secara tunai dan/atau dengan pola angsuran dengan proses cepat dalam jangka waktu tertentu dan fleksibel. Pihak-pihak yang terlibat pembiayaan program MULIA adalah Pegadaian Syariah selaku pembeli atau yang membiayai pembelian barang, Nasabah sebagai pemesan barang yang dalam pembiayaan program MULIA barang komoditinya adalah emas logam mulia, dan Supplier atau pihak yang diberi kuasa oleh Pegadaian untuk menjual barang (PT.Aneka Tambang).

Prosedur pembiayaan program MULIA di Pegadaian Syariah adalah Mengisi Formulir Mulia sesuai dengan KTP atau kartu pengenal lainnya, Foto Kopi KTP dan uang muka. Pihak pegadaian melakukan transaksi atau pemesanan di Galeri 24 secara online dan kemudian mencetak akad. Nasabah menandatangani kesepakatan tertulis yang berisi tentang perhitungan penjualan, jadwal angsuran, akad Program MULIA dan akad Rahn sebanyak 2 rangkap.

Pedoman dalam pelaksanaan pembiayaan program MULIA yaitu pada fatwa Dewan Syariah Nasional No : 04/DSN-MUI/IV/2000 tentang Murabahah. 23 Pelaksanaan pembiayaan program MULIA dalam menggunakan akad yaitu atas persetujuan atau kesepakatan yang di buat bersama antara pegadaian dan nasabah atas sejumlah pembelian emas batangan logam mulia dengan jangka waktu tertentu disertai keuntungan dan biaya-biaya yang disepakati.

Adapun mekanisme perjanjian Pembiayaan program MULIA adalah Pegadaian Syariah ( pihak pertama) membiayai pembelian barang berupa emas batangan yang dipesan oleh nasabah atau pembeli (pihak kedua)kepada suplier (pihak ketiga). Pembelian barang atau komoditi oleh nasabah (pihak kedua) dilakukan dengan sistem pembayaran tangguh. Didalam pelaksanaannya, pegadaian membelikan barang yang diperlukan nasabah atas nama Pegadaian. Pada saat yang bersamaan Pegadaian menjual barang tersebut kepada nasabah dengan harga pokok ditambah sejumlah keuntungan untuk dibayar oleh nasabah pada jangka waktu tertentu.

\footnotetext{
${ }^{23}$ Wawancara, Dony Bachtiar Pimpinan cabang PT Pegadaian Syariah, Tanggal 13 Januari 2015
} 
Kemudian barang komoditi yang dibeli yaitu berupa emas logam mulia dijadikan jaminan (marhun) untuk pelunasan sisa hutang nasabah kepada pihak Pegadaian Syariah. Setelah semua hutang nasabah lunas, maka emas logam mulia beserta dokumendokumennya diserahkan kepada nasabah. Sehingga pelaksanaan pembiayaan Program MULIA terjadi dua akad yaitu akad murabahah dan rahn yang di laksanakan pada masing-masing akad/perjanjian.

Adapun perjanjian yang tertera di masing-masing akad yaitu sebagai berikut :

\section{a. Bentuk Akad Murabahah}

Pada pasal 5 Jaminan yang berbunyi yaitu jaminan pelunasan atas pembelian LM Emas maka pihak kedua menyerahkan objek jual beli kepada pihak pertama sampai dengan pelunasan seluruh kewajiban pihak kedua. Jaminan pelunasan utang dilakukan dalam bentuk akad gadai (rahn) dan pasal 6 Penyerahan Jaminan berbunyi yaitu pihak pertama akan menyerahkan objek jual beli yang dijaminkan oleh pihak kedua setelah pelunasan seluruh kewajiban. Apabila pelunasan dipercepat oleh pihak kedua dari jangka waktu akad yang telah disepakati, maka penyerahan objek jual beli yang dijaminkan minimal pada bulan ketiga dari sejak akad ditandatangani oleh para pihak.

\section{b. Bentuk Akad Rahn}

Bentuk akad perjanjian pada pembiayaan Program MULIA terdiri dari dua akad yaitu akad murabahah sebagaimana akad nomor

0114211221263122/MULIA BARU/2015 tanggal 13 Januari 2015 yang isinya sebagai berikut :

Pihak pertama (pegadaian syariah) dengan pihak kedua (nasabah/pembeli) sepakat dan menyetujui menandatangani Akad tentang Rahn Logam Mulia Emas karyawan yang selanjutnya di sebut Akad, dengan ketentuan dan syarat-syarat sebagaimana tercantum dalam pasal 1 yatu Pihak kedua telah berutang kepada pihak pertama yang timbul akad murabahah dan berkewajiban untuk membayar pelunasan angsuran logam mulia emas dan pasal dua yaitu pihak kedua menyerahkan LM Emas kepada pihak pertama sebagai marhun (barang jaminan) atas hutang pihak kedua a. Analisis Penundaan Penyerahan Objek Akad Pembiayaan Program MULIA

Pembiayaan program Mulia di Pegadaian Syariah terdapat 2 (dua) akad yaitu murabahah dan rahn. Dalam prakteknya, Ada beberapa penyebab ditundanya objek pada saat penyerahan yaitu dijadikan sebagai jaminan pada saat dilakukan rahn sebagaimana yang telah dijelaskan dalam akad program MULIA. Jaminan dalam murabahah dimaksudkan untuk menjaga agar si pemesan tidak main-main dengan pesanan sehingga si 
pembeli dapat meminta si pemesan (pemohon/nasabah) suatu jaminan ( $r a h n)$ untuk dipegangnya. Dalam teknis operasionalnya, barang-barang yang dipesan dapat menjadi salah satu jaminan yang bisa diterima untuk pembayaran utang. $^{24}$

Adapun pelaksanaan penundaan penyerahan objek dalam masing-masing akad pembiayaan Program MULIA sebagai berikut :

\section{a. Akad Murabahah}

Praktek yang dilakukan di pegadaian syariah telah sesuai dalam fatwa Dewan Syariah Nasional No. 04/DSN-MUI/IV/2000 tentang murabahah, bahwa jaminan dalam murabahah dibolehkan, agar nasabah serius dengan pesanannya, bank dapat meminta nasabah untuk menyediakan jaminan yang dapat dipegang. Oleh karena itulah objek boleh dijaminkan sebagai pembayaran hutang tetapi dalam fatwa DSN tidak dijelaskan barang yang dijaminkan boleh menjadi barang jaminan. Kemudian diatur lagi dalam DSN nomor 77/DSNMUI/V/2010 tentang jual beli emas tidak tunai yang dijelaskan bahwa Jual beli emas secara tidak tunai, baik melalui jual beli biasa atau jual beli murabahah, hukumnya boleh

24 Muhammad syafi'I Antonio, Bank Syariah dari Teori ke Praktek, (Depok : Gema Insani, 2001), Hal. 105 (mubah,ja'iz) selama emas tidak menjadi alat tukar yang resmi (uang).

Dengan ketentuan Harga jual (tsaman) tidak boleh bertambah selama jangka waktu perjanjian meskipun ada perpanjangan waktu setelah jatuh tempo, emas yang dibeli dengan pembayaran tidak tunai boleh dijadikan jaminan (rahn), dan emas yang dijadikan jaminan atau dijadikan obyek akad lain yang menyebabkan perpindahan kepemilikan. Selain itu Dalam fatwa Dewan Syariah Nasional No : 92/DSN-MUI/IV/2014 tentang pembiayaan yang disertai rahn menyimpulkan bahwa dalam fatwa ini yang dimaksud dengan akad murabahah salah satunya, ketentuan terkait akad rahn dibolehkan hanya atas utang-piutang yang antara lain timbul karena akad qardh, jual beli yag tidak tunai, atau akad sewamenyewa (ijarah) yang pembayaran ujrahnya tidak tunai. ${ }^{25}$

Menurut Muhammad Syafi'I dalam bukunya menjelaskan bahwa objek dijadikan rahn sebagai produk pelengkap artinya sebagai akad tambahan (jaminan/collateral) terhadap produk lain seperti dalam pembiayaan murabahah. Bank dapat

${ }^{25}$ Fatwa Dewan Syariah Nasional No : 92/DSNMUI/IV/2014 tentang Pembiayaan yang Disertai Rahn, hal. 4-5 
menahan barang nasabah sebagai konsekuensi akad tersebut. ${ }^{26}$

Akad murabahah merupakan jual beli barang pada harga asal dengan tambahan keuntungan yang disepakati antara lembaga dan nasabah dengan teknisnya barang sudah ada ditangan lembaga kemudian diserahkan segera kepada nasabah dengan pembayaran dilakukan secara kredit.

\section{b. Akad Rahn}

Pada dasarnya praktek rahn yang telah dilakukan oleh lembaga Pegadaian telah sesuai dengan ekonomi Islam yaitu barang dijadikan sebagai jaminan utang nasabah pada pembiayaan program MULIA, sebagaimana yang telah dijelaskan dalam DSN nomor 77/DSN-MUI/V/2010 tentang jual beli emas tidak tunai dan DSN Nomor 92/DSN-MUI/IV/2014 tentang pembiayaan yang disertai rahn.

Dalam Islam pun telah dijelaskan bahwa gadai berasal dari kata Arab al-rahn berarti tetap, disebut tetap karena barang gadai ada pada pemberi pinjaman hingga utang dibayar. Gadai juga berarti jaminan utang, gadaian, barang yang digadaiakan, hipotek, atau al-habs (penahanan), yaitu menahan salah satu hak milik peminjaman sebagai jaminan atas pinjaman utang. Kata arhana

\footnotetext{
26 Muhammad syafi'I Antonio, Bank Syariah dari Teori ..., hal. 130

berarti menjadikan sesuatu sebagai jaminan hutang. $^{27}$

Namun praktek tersebut belum sempurna jika objek tersebut belum diserahterimakan ke nasabah. Menurut ulama Hanafiyah, rukun rahn adalah ijab dan qabul oleh orang yang menggadaikan dan menerima gadai sebagaimana dalam akad-akad bisnis yang lain, dan ijab dan qabul itu tidak sempurna kecuali bila disertai dengan serah terima barang gadai. Para Ulama mengatakan bahwa rukun gadai itu ada empat yaitu ijab dan qabul, dua orang yang berakad (rahin dan murtahin), barang yang digadaikan (marhun) dan utang (marhun bih). ${ }^{28}$

Dengan demikian, penundaan penyerahan objek akad Pembiayaan program MULIA dalam akad murabahah dan rahn sebagai jaminan tidak menyalahi kaidah ekonomi Islam. Tetapi Sebaiknya penyerahan objek akad pada saat transaksi diperlihatkan atau ada dalam transaksi. Sebagaimana yang telah dijelaskan dalam hadis Nabi :

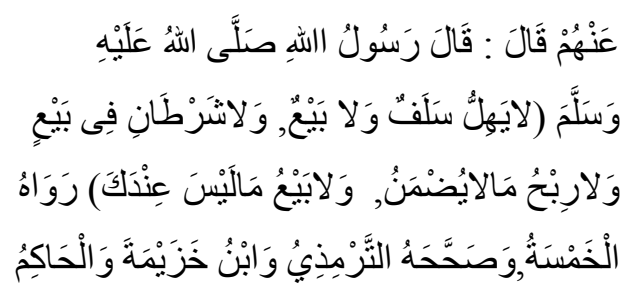

Dari Amr putera Syu'aib dari ayahnya, dari kakeknya, ra., iya berkata : bersabda Rasulullah saw. "tidak dihalalkan pinjaman dan penjualan dan tidak halal dua syarat

\footnotetext{
${ }^{27}$ Idri, Hadis...., (Jakarta : Kencana, 2015), Hal.
} 197 
dalam satu penjualan, tidak halal keuntungan dari hasil penjualan barang yang tidak ada tanggungannya. Dan tidak halal menjual barang yang tidak ada padamu (abstrak) .

(Hadits diriwayatkan oleh Imam Lima). Imam Tirdmidzi, Imam khuzaimah dan Imam Hakim menyatakan "shahihnya" hadits ini. ${ }^{29}$

Hadis di atas menjelaskan bahwa barang itu harus ada. Maka tidak sah menjual barang yang tidak ada atau belum ada.

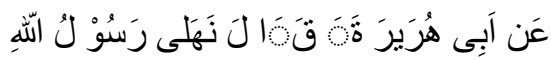

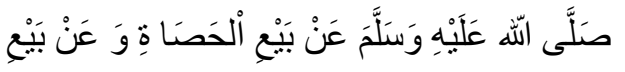

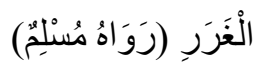

Dari Abu Hurairah r.a Berkata Rasulullah SAW melarang jual beli dengan Lempar batu (kerikil) dan jual beli gharar. (HR Muslim). ${ }^{30}$

Hadis ini menjelaskan bahwa barang dapat diserahkan saat akad berlangsung atau pada waktu yang telah disepakati bersama, ketika transaksi berlangsung, kemampuan untuk menyerahkan barang disyaratkan tidak ada kesulitan. ${ }^{31}$

Agar akad lebih sempurna hendaknya diperlihatkan barang terlebih dahulu dan kemudian dapat diserahterimakan khusus pada saat akad rahn dalam praktek pembiayaan program MULIA. Jika nasabah

29 Alhafizh Ibn Hajar A'Asqalani, Bulughul Maram. Terj.... hal. 392

30 AbuBakar Muhammad, Terjemahan sulubus salam III, (Surabaya : Al-Ikhlas. 1995), Hal. 52

${ }^{31}$ Idris, Hadis .... hal 174 selesai membayar hutang sebelum jatuh tempo, barang pun belum bisa langsung diserahterimakan karena di dalam akad telah tertera barang dapat diserahterimakan minimal pada bulan ketiga.

Alasan pegadaian menunda penyerahan objek akad karena nasabah belum melunasi pembiayaan program MULIA tersebut sehingga belum dapat diserahkan kepada nasabah, berbeda dengan barang bergerak yang harus memiliki bukti kepemilikan seperti kendaraan bermotor. Seandainya diserahkan di awal maka akan terjadi kesulitan dalam pembiayaan berikutnya, karena pegadaian tidak memegang kepemilikan barang tersebut.

Pembelian barang diserahkan di kemudian hari, sedangkan pembayaran dilakukan di muka maka akad ini adalah akad salam jika pihak lembaga ingin melakukan tambahan akad dalam pembiayaan, menyelesaikan dulu pembiayaan dalam akad murabahah setelah selesai akad melakukan pembelian dalam akad murabahah, baru kemudian melakukan akad rahn selanjutnya.

Pada program pembiayaan MULIA lebih bersifat konsumtif bukan produktivitas yang dapat membuat masyarakat berupaya mengerahkan sumber daya supaya mengembangkan potensi, baik sumber daya manusia maupun sumber daya alam di sekitar keberadaan rakyat. Pembiayaan ini bertujuan untuk investasi pemenuhan kebutuhan masyarakat masa yang mendatang. Maka dai 
iru, pemberdayaan ekonomi masyarakat dalam hal ini adalah pemberdayaan ekonomi masyarakat dalam hal investasi.

Pegadaian mengajarkan masyarakat bagaimana cara berinvestasi dengan mengunakan emas. Semua fasilitas telah disediakan oleh pihak pegadaian dan masyarakat hanya berupaya dalam pembayaran pelunasan hutang saja. Bukan hanya itu, pegadaian juga melakukan seminar invetasi emas untuk memberikan pengetahuan bagi masyarakat, namun sangat disayangkan seminar ini untuk nasabah yang telah melakukan investasi sebelumnya, kebanyakan itu masyarakat kalangan menengah keatas yang melakukan investasi ini. Dengan kata lain belum banyak masyarakat menengah kebawah yang melakukan pembiayaan. Padahal yang paling penting adalah masyarakat menengah kebawah yang dapat meningkatkan taraf hidupnya yang lebih baik. Sebenarnya tidak tertutup kemungkinan masyarakat menengah kebawah dapat melakukan investasi ini, karena Pegadaian telah memberikan fasilitas dalam pembiayaan misalnya model arisan yang dapat mempermudah pembayaran utang karena dilakukan bersama-sama. Namun jika masyarakat menengah kebawah yang masih susah memenuhi kebutuhannya sehari-hari maka soal investasi tidak begitu menarik baginya. Pembiayaan MULIA ini kurang cocok bagi mereka dan pegadaianpun juga tidak terlalu gencar berupaya untuk sosialisasi kepada masyarakat menengah kebawah karena kerugian yang didapat jika nasabah tidak mampu membayar hutangnya.

\section{PENUTUP \\ Kesimpulan}

Berdasarkan hasil penelitian dan pembahasan sebagaimana telah diuraikan di atas, penulis menarik sebagai kesimpulan penelitian ini yaitu pelaksanaan penundaan penyerahan Objek Akad murabahah pada pembiayaan program MULIA di Pegadaian syariah cabang Bengkulu belum sesuai dalam persfektif ekonomi Islam karena tidak dilakukan serah terima barang segera kepada nasabah.

b. Rekomendasi

1. Jika pembelian barang diserahkan di kemudian hari, sedangkan pembayaran dilakukan di muka maka akad ini adalah akad salam.

2. Akad murabahah boleh disertai rahn dengan pelaksanaan diselesaikan akad murabahah terlebih dahulu, setelah selesai baru melakukan akad rahn disertai dengan dengan barang yang telah ada di tangan nasabah.

\section{DAFTAR PUSTAKA}

Buku-Buku :

Adiwarman. karim, 2011, BANK ISLAM Analisis Fiqih dan Keuangan, Jakarta : PT. RajaGrafindo Persada. 
Al-Arif, M Nur Rianto. 2010. Dasar-Dasar Pemasaran Bank Syariah. Bandung: Alfabeta

Alhafizh Ibn Hajar A'Asqalani, Bulughul Maram. Terj. Moh. Machfuddin Aladin, Semarang : PT. Karya Toha Putra

Andi Prastowo, 2010, Menguasai TeknikTeknik Koleksi Data Penelitian Kualitatif, Jogjakarta : Diva Press.

Assalamah, 2001, Alquran dan Terjemahannya, Semarang: CV. Asy-Syifa',

Dewan Syariah Nasional MUI, Pembiayaan yang Disertai Rahn, Jakarta : National Sharia BoardIndonesian Council of Ulama

Dewan Syariah Nasional MUI. Murabahah. Jakarta: National Sharia Board-Indonesian Council of Ulama

Dewan Syariah Nasional MUI. Jual Beli Emas Tidak Tunai. Jakarta: National Sharia Board-Indonesian Council of Ulama

Dewi, Gemala. 2007. Aspek-Aspek Hukum dalam Perbankan dan Perasuransian Syariah di Indonesia.

Jakarta: Kencana

Djuwaini Dimyauddin, 2010, Pengantar

Fiqh Muamalah, Yogyakarta : pustaka Pelajar.

Idri, 2015, Hadis Ekonomi, Jakarta : Kencana
Kasmir, 2011, Bank dan Lembaga Keungan Lainnya, Jakarta : Rajawali press.

Muhammad syafi'I Antonio, Bank Syariah dari teori ke praktek, (Depok : Gema Insani, 2001), Hal. 105

P3EI, 2012, Ekonomi Islam, Jakarta : PT. RajaGrafindo Persada.

PPHIM, 2009, Kompilasi Hukum Ekonomi Syariah, Jakarta : Prenada Media Group

Purnamasari, Irma Devita dan Suswinarno. 2011. Panduan Lengkap Hukum Praktis Populer. Bandung: Kaifa

Sangadji Mamang etta dan Sopiah, 2010, Metodelogi Penelitian, Yogyakrta : Andi Yogyakarta.

Sholikul Muhammad hadi, 2003 'Pegadaian Syariah. Jakarta :salemba diniyah,

Soemitra Andri. 2012. Bank dan Lembaga Keuangan Syariah. Jakarta : Kencana Prenada Media Group

Sofyan Ade Mulazid, 2012, Kedudukan Sistem Pegadaian Syariah, Jakarta : Kementerian Agama RI

Sudarsono Heri, 2004, Bank Lembaga Keuangan Syarih, Yogyakarta : Ekonisia.

Sugiyono, 2012, Metode Penelitian Kombinasi (Mixed Methods), Bandung : Alfabeta.

Syafe'I Rachmat, 2004, Fiqih Muamalah, Bandung : Pustaka Setia. 
Syafri Sofyan harahap, dkk, 2010, Akuntansi Pervankan Syariah, Jakarta : Barat LPEE Usakti.

Yaya, Rizal, Aji Erlangga Martawirwja dan Ahim Abdurahim. 2009. Akuntansi Perbankan Syariah: Teori dan Praktik Kontemporer. Jakarta: Salemba Empat

Wiroso, 2010, Akuntansi Transaksi Syariah, Jakarta: LPFE-Usakti

Skripsi/Tesis :

Desmi Nur Hasanah. 2013. Pelaksanaan Rahn (Gadai) Emas pada Bank Pembiayaan Rakyat Syariah (BPRS) Safir Bengkulu dalam perspektif Ekonomi Islam. IAIN: Skripsi, fakultas Syariah dan Ekonomi Islam Hikmawati Nurul. 2013. Analisis Fatwa DSN Tentang Jual Beli Emas Secara Tidak Tunai (Murabahah Emas).

Muklas. 2010. Implementasi Gadai Syariah dengan Akad Murabahah
Dan Rahn (Studi Di Pegadaian Syariah Cabang Mlati Sleman Yogyakarta). Surakarta : Skripsi, Universitas Sebelas Maret

Nur, Khori Azizah. 2012. Pandangan Masyarakat terhadap Pelaksanaan Gadai di Pegadaian Syariah Cabang Bengkulu. IAIN: Skripsi, fakultas Syariah dan Ekonomi Islam Internet :

Admin. http//www.pegadaian.co.id (akses Tanggal 11 desember 2014)

Wikipedia,http://id.wikipedia.org/wiki/Pegad aian_\%28perusahaan\%29 (akses Tanggal 28 november pukul 10:00)

Admin.http://www.antam.com/index.php?o ption=com_content\&task=view\&id $=32 \&$ Itemid $=2$, (akses Tanggal 22 september 2014)

Hikmawati,http://hikmawati92.blogspot.co m ( akses 21 september 2014) 